\title{
- Low flow controls on benthic and hyporheic macroinvertebrate assemblages during supra-seasonal drought
}

\author{
R. Stubbington, ${ }^{1}$ P. J. Wood ${ }^{1 *}$ and A. J. Boulton ${ }^{2}$ \\ ${ }^{1}$ Department of Geography, Loughborough University, Loughborough, Leicestershire, LE11 3TU, UK \\ ${ }^{2}$ Ecosystem Management, University of New England, Armidale 2350, New South Wales, Australia
}

\begin{abstract}
:
Despite the widely accepted importance of the hyporheic zone as a habitat for stream macroinvertebrates during floods, few data exist regarding community composition and distribution during periods of low flow or drought in perennial streams. Integrating research on hyporheic invertebrates with results from a long-term study of a UK river provided the opportunity to examine how surface and hyporheic macroinvertebrate communities respond to inter-annual variability in river flow and periods of groundwater drought. Changes in the riverine macroinvertebrate community associated with low flow included a reduction in species richness and the number of individuals per sample, particularly aquatic insects. The hyporheic community was characterized by a relatively homogeneous composition during a period of severe low flow, punctuated by short-term changes associated with variation in water temperature rather than changes in discharge. We present a conceptual model of the processes influencing benthic and hyporheic invertebrates under low-flow conditions. Previous studies have seldom integrated these two assemblages and their interactions. The model presented highlights the potential importance of surface water and hyporheic zone linkages for riverine invertebrate communities under a range of flow conditions. Copyright (c) 2009 John Wiley \& Sons, Ltd.
\end{abstract}

KEY WORDS benthos; hyporheos; low flows; drought; hyporheic processes; invertebrates; groundwater

Received 1 October 2008; Accepted 23 January 2009

\section{INTRODUCTION}

Natural low flows associated with droughts originate from a deficit of precipitation (Smakhtin, 2001). Droughts can occur in almost any biogeographical setting, although the onset of an individual event can be difficult to determine (Humphries and Baldwin, 2003; Smakhtin and Schipper, 2008). Following an initial deficit of precipitation (meteorological drought), river discharge and water levels in other surface water bodies decline leading to 'hydrological drought' within the drainage basin and/or wider region. Ultimately, without sufficient meteorological input (recharge), groundwater levels within aquifers will decline, resulting in a 'groundwater drought', the impact of which may be compounded by anthropogenic water resource requirements for agricultural, industrial and domestic uses (Tallaksen and van Lanen, 2004).

River flow regime variability and low flows associated with drought conditions have been widely studied in lotic systems (Smakhtin, 2001), and their role in structuring in-stream communities is now recognized (Lytle and Poff, 2004; Monk et al., 2008). However, due to the complexities of defining and determining the onset of events, hydroecological data documenting responses of in-stream communities to droughts, from their onset to

* Correspondence to: Dr P. J. Wood, Department of Geography, Loughborough University, Loughborough, Leicestershire, LE11 3TU, UK. E-mail: p.j.wood@lboro.ac.uk recovery, are relatively limited compared with studies reporting the ecological responses to floods (Suren and Jowett, 2006; Lake, 2007). In addition, there are marked differences in the manifestation of drought between individual catchments and our understanding of how instream ecological communities respond varies regionally (Demuth and Young, 2004).

The response of in-stream organisms to drought largely reflects the predictability and severity, including the duration, of the event (Lake, 2003). The greatest understanding of the role of drought within lotic ecosystems is for those subject to predictable 'seasonal' droughts in semi-arid environments (Acuna et al., 2005; Bonada et al., 2006). Those communities experiencing regular drought, typical of Mediterranean environments, frequently display behavioural and physiological adaptations that enable them to withstand prolonged low flows or cessation of flow (Bonada et al., 2006). Ecological data available for droughts within temperate environments are comparatively limited (Wood and Armitage, 2004; Lake, 2007). Aquatic invertebrate communities in temperate zone perennial lotic ecosystems subject to irregular and/or high magnitude events are seldom adapted to withstand the extreme conditions and, as a result, are usually severely impacted when flow declines or ceases (Wright and Berrie, 1987; Caruso, 2002; Lake, 2007).

Droughts are 'ramp disturbances' (sensu Lake, 2003) that gradually increase in intensity over time. The 


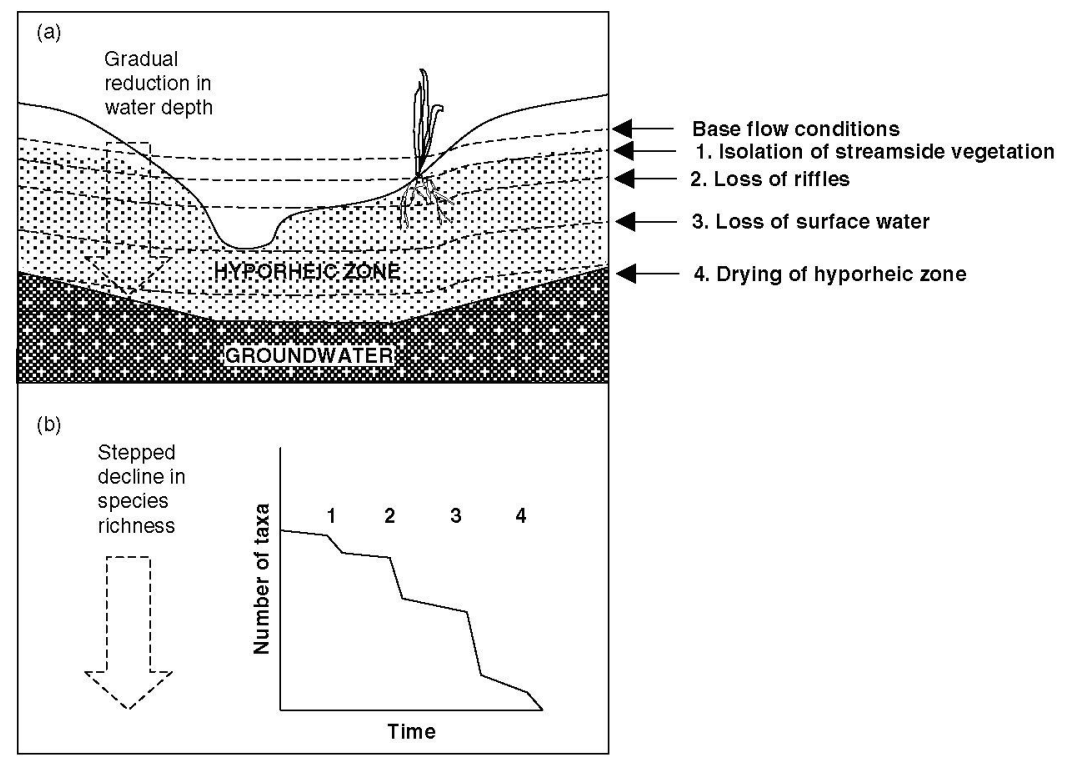

Figure 1. Changes in river stage and macroinvertebrate assemblage composition associated with supra-seasonal drought: (a) cross-section of a conceptualized channel during critical stages of drying; (b) hypothesized 'stepped' changes in species richness corresponding to these critical stages (adapted from Boulton, 2003)

response of lotic communities to drought and reduced river discharge has been characterized by gradual (ramp) changes punctuated by significant 'stepped' responses as thresholds between critical levels are crossed (Boulton, 2003). These steps reflect the gradual reduction in river stage (water depth) coinciding with ecologically significant threshold changes in discharge or the exposure of particular habitats. Examples include the isolation of streamside vegetation, cessation of flow, the isolation of surface water into pools, loss of surface water and far less studied the decline or loss of free water within the hyporheic zone (Figure 1).

The functional significance of the hyporheic zone has gained increasing prominence in recent years (Boulton et al., 1998; Boulton, 2007). This reflects the recognition that the habitat supports a number of unique (obligate) taxa and has wider linkages in the landscape with other surface and groundwater habitats (Malard et al., 2002). There is increasing evidence that processes operating within the hyporheic zone may significantly contribute to maintaining ecosystem health (Tomlinson et al., 2007; Pinay et al., 2009) through the provision of key ecosystem services (Boulton et al., 2008). It is now widely recognized that the hyporheic zone is a focal point for important biogeochemical processes and the transient storage of nutrients (Mulholland et al., 2008; Pinay et al., 2009). In addition, the exchange of water within the hyporheic zone may locally influence dissolved oxygen concentrations, thermal properties and sedimentary characteristics required to support salmonid fisheries (Malcolm et al., 2005).

In this article, we synthesize the existing hydroecological data available for the Little Stour River (Kent, UK) to examine macroinvertebrate community responses to river flow variability and drought-related low flows. The benthic macroinvertebrate hydroecology of the river has been extensively studied for over a decade in relation to flow variability, in particular the influence of low flows associated with droughts (Wood and Petts, 1999; Wood et al., 2000; Wood and Armitage, 2004). We present data from a long-term study of inter-annual variability of the benthic community (1992-1999) and data collected as part of a detailed monthly investigation of the benthic and hyporheic invertebrate communities during a groundwater drought in 2006. In particular, we assess whether the benthic and hyporheic fauna respond similarly to drought and whether there is evidence of marked 'step responses' to the ramp disturbance of drought in the hyporheic zone where effects of drying are hypothesized to be buffered by the saturated sediments. These results are used along with other published information to develop a conceptual model to demonstrate how interactions between surface and groundwater influence hydrological processes within the hyporheic zone which, in turn, may structure habitat availability and the benthic and hyporheic zone communities.

\section{9 \\ STUDY SITE

The Little Stour River (Kent, UK) is a small lowland chalk stream, $11.5-\mathrm{km}$ long, draining a catchment area of approximately $213 \mathrm{~km}^{2}\left(51.275^{\circ} \mathrm{N} 1.168^{\circ} \mathrm{E}\right)$. The highly permeable nature of the catchment results in a low drainage density, which is typical of groundwaterdominated streams. The sedimentary calcareous rocks result in relatively high conductivities ( $c$ a $580 \mu \mathrm{s} \mathrm{cm}^{-1}$ ). Mean annual precipitation within the catchment is $c a$ $650 \mathrm{~mm}$ per year (Wood and Petts, 1994). The river is usually perennial below the spring head, although a $1-\mathrm{km}$ reach has been dewatered on three previous occasions in the last century during supra-seasonal drought events (1949, 1991-1992 and 1996-1997), with the latter two 
1 events being studied in detail (Wood and Armitage,

2 2004). A subsequent drought event impacted the site 3 and much of southern England between 2004 and 2006 4 (Marsh, 2007), although the Little Stour maintained 5 perennial flow along its entire length throughout this 6 period.

\section{METHODS}

The macroinvertebrate community of the river was sampled annually (1992-1999) from nine sites along the upper river. Macroinvertebrates were sampled during base flow conditions (late August-early September) using a semi-quantitative kick-sampling technique over a 2-min period (Wood and Armitage, 2004). During 2006 , both benthic and hyporheic invertebrate communities were sampled from four riffle sites on the river between April 2006 and October 2006. This coincided with the latter stages of a supra-seasonal drought resulting from below-average rainfall between November 2004 and June 2006 (Marsh et al., 2007). For further details of site locations and physical characteristics, including relative flow permanence, see Wood and Petts (1999) and Wood et al. (2000).

During the intensive study in 2006 , five benthic samples were collected at each of the four riffle sites on the upper river each month using a Surber sampler $\left(0 \cdot 1 \mathrm{~m}^{2}\right.$, $250-\mu \mathrm{m}$ mesh net) over a 30 -s period, disturbing the substratum to a depth of $50 \mathrm{~mm}$. Associated with each benthic sample, hyporheic invertebrate samples were collected from $20-\mathrm{cm}$ deep polyvinylchloride (PVC) wells (25- $\mathrm{mm}$ internal diameter) following the procedure outlined by Boulton and Stanley (1995). PVC wells were inserted into the riverbed using a stainless steel bar and samples can be collected immediately. The primary advantages of this technique over others, such as the Bou-Rouch sampler (Bou and Rouch, 1967) are that: (i) the small size of the well minimizes disturbance of surrounding sediments and it can remain in place to allow collection of subsequent samples; (ii) the sampler does not require priming with water and as a result is fully quantitative and (iii) the sample does not pass through the mechanism of the pump and as a result specimens are less prone to damage. Each sample comprised 61 of hyporheic water pumped from the base of the well using a bilge pump. For each hyporheic water sample, $\mathrm{pH}$, conductivity, dissolved oxygen concentration, and water temperature were measured (Hanna Instruments) before passing the sample through a $90-\mu \mathrm{m}$ mesh sieve to isolate the fauna. Benthic water characteristics $(\mathrm{pH}$, conductivity, dissolved oxygen concentration and water temperature) were also recorded before the collection of faunal samples. Benthic and hyporheic invertebrate samples were preserved in the field in $4 \%$ formaldehyde, and returned to the laboratory for processing and identification. In the laboratory, invertebrate taxa were identified to species level except Baetidae (Ephemeroptera-mayfly larvae), Chironomidae (non-biting midge larvae) and Oligochaeta (worms).
To examine long-term temporal trends within the faunal data, box-plots or error bar graphs were assessed. The influence of inter-annual flow variability was investigated using the number of individuals and the number of taxa per sample (species richness). These two measures were standardized before analysis by calculating $z$-scores for individual sample sites from 1992 to 1999 ( site mean $=0$ and standard deviation $=1$ ). This method of standardization does not alter the shape of the timeseries curves at individual sites or correlation coefficients with independent variables, thus allowing comparisons between the responses of multiple sites to the same external factor (discharge variability). To examine the influence of antecedent hydrological conditions on the most common taxon recorded on the Little Stour, the amphipod shrimp Gammarus pulex (L.), mean annual and monthly discharge characteristics up to 12 months before sample collection were examined using scatter plots and by calculating correlation coefficients between river flow (discharge) characteristics and the standardized number of individuals per sample for the four riffle sites (also used during the 2006 study period). One way analysis of variance (ANOVA) was used to examine temporal differences between benthic and hyporheic invertebrate communities during 2006 following application of Levene's test to ensure that variances were homogeneous. Differences between individual months were examined using Tukey's post-hoc multiple comparisons tests to identify where significant differences occurred. All analyses were undertaken using the package SPSS (Version 15).

\section{RESULTS}

\section{Benthic community response to inter-annual flow} variability

The influence of three supra-seasonal droughts recorded during the study period (1992, 1996-1997 and 2005-2006) is clear on the long-term hydrograph of the Great Stour River (Figure 2) for which a continuous flow series is available and for which the Little Stour forms the largest tributary. The influence of the drought periods is evident for the Little Stour River between 1992 and 1999 (Figure 3a). However, the meteorological and hydrological droughts marking the onset of the supra-seasonal events (Summer, 1995 and Autumn, 2004) were characterized by relatively high discharge on several occasions due to high groundwater levels ( $\mathrm{H}$ on Figure 2). Perennial flow was maintained throughout the Great Stour during the study period although a $1-\mathrm{km}$ reach of the Little Stour was dewatered during 1991-1992 and 1996-1997 when extreme supra-seasonal groundwater drought conditions prevailed. A total of 87 taxa from 48 families were recorded dur- 113 ing the study period, ranging from only 42 taxa in 1992114 to 60 taxa in 1995. The standardized number of individu- 115 als and species richness responded directly to changes in 116 the discharge regime (Figure 3). Supra-seasonal drought 117 conditions during 1992 and 1996-1997 resulted in low 118 4 16 


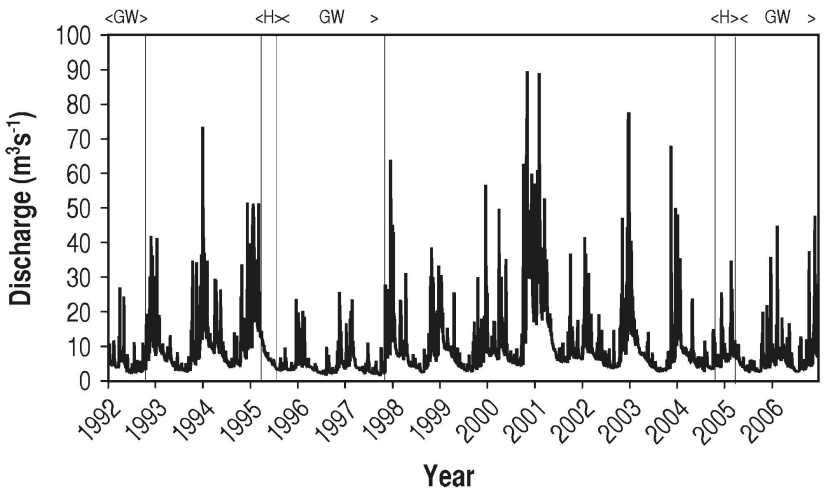

Figure 2. Hydrograph of mean daily discharge $\left(\mathrm{m}^{3} \mathrm{~s}^{-1}\right)$ for the Great Stour River at Horton (1992-2006). GW indicates periods of supraseasonal groundwater drought and $\mathrm{H}$ indicates the onset of meterological and hydrological drought conditions
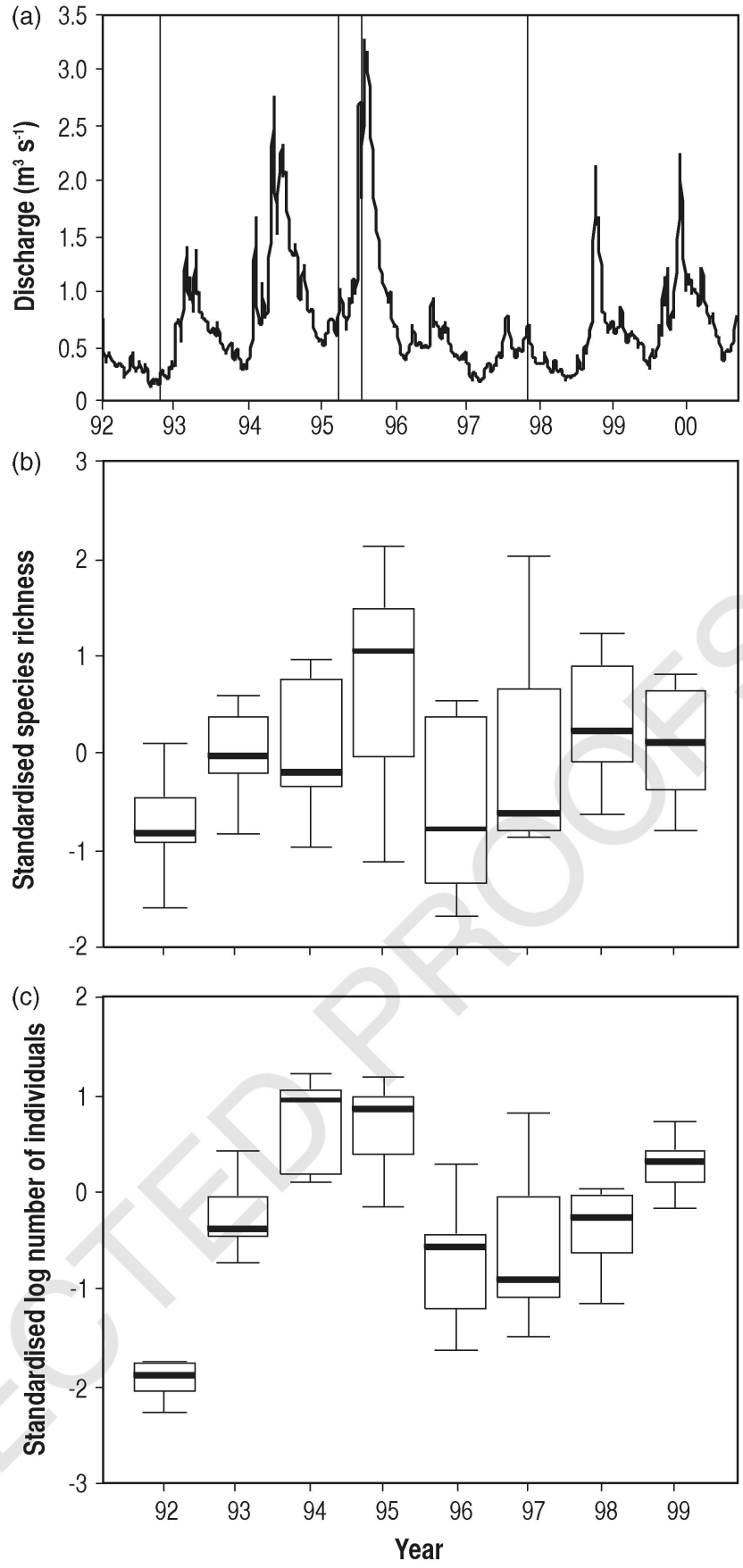

Figure 3. Time series of river flow and box-plots of macroinvertebrate assemblage indices 1992-1999 for the Little Stour River: (a) hydrograph of mean daily discharge $\left(\mathrm{m}^{3} \mathrm{~s}^{-1}\right)$ for the Little Stour River at West Stourmouth-see Figure 2 for definition of vertical lines; (b) standardized species richness and (c) standardized number of individuals per sample $\left(\log _{\mathrm{e}}\right.$ transformed)

(Tukey's post-hoc test: all $P<0.05$ ) (Figure 5b). This coincided with a significant reduction in the number of aquatic insect taxa $\left(F_{6,140}=2.79, P=0.01\right)$ particularly mayflies (Ephemeroptera): Baetidae, Serratella ignita and Caenis spp. and caddisflies (Trichoptera): Hydropsyche siltalai, Sericostoma personatum and Athripsodes bilineatus. As a result, the percentage of aquatic insect larvae within the community (including mayflies, caddisflies and Diptera such as chironomid midge larvae) was significantly lower during both June and July

Hydrol. Process. 23, 0-0 (2009) DOI: $10.1002 / \mathrm{hyp}$ 
Table I. Pearson correlation coefficients between standardized $\log _{\mathrm{e}}$-Gammarus pulex and lagged discharge variables for riffles sites ( $n=4$ sites) on the Little Stour River (1992-1999)

Discharge variable

\begin{tabular}{lc}
\hline August $(M-1)$ & $0 \cdot 78^{* *}$ \\
July $(M-2)$ & $0 \cdot 82^{* *}$ \\
June $(M-3)$ & $0 \cdot 83^{* *}$ \\
May $(M-4)$ & $0 \cdot 89^{* *}$ \\
April $(M-5)$ & $0 \cdot 88^{* *}$ \\
March $(M-6)$ & $0 \cdot 89^{* *}$ \\
February $(M-7)$ & $0 \cdot 91^{* *}$ \\
January $(M-8)$ & $0 \cdot 84^{* *}$ \\
December $(M-9)$ & $0 \cdot 72^{* *}$ \\
November $(M-10)$ & $0 \cdot 69^{* *}$ \\
October $(M-11)$ & $0 \cdot 77^{* *}$ \\
September $(M-12)$ & $0 \cdot 53^{*}$ \\
3 months before sampling $(Y-3)$ & $0 \cdot 47^{*}$ \\
6 months before sampling $(Y-6)$ & $0 \cdot 54^{*}$ \\
9 months before sampling $(Y-9)$ & $0 \cdot 51^{*}$ \\
12 months before sampling $(Y-12)$ & $0 \cdot 50^{*}$
\end{tabular}

All samples collected from last week of August to the first week of September throughout the study period. $M-n$ refers to the mean daily discharge in the month $(M)$ before sample collection (1-12). $Y$-n refers to the mean daily discharge in the 3,6 and 12 months before samples collection. ${ }^{*} P<0.05 ;{ }^{* *} P<0.005$.

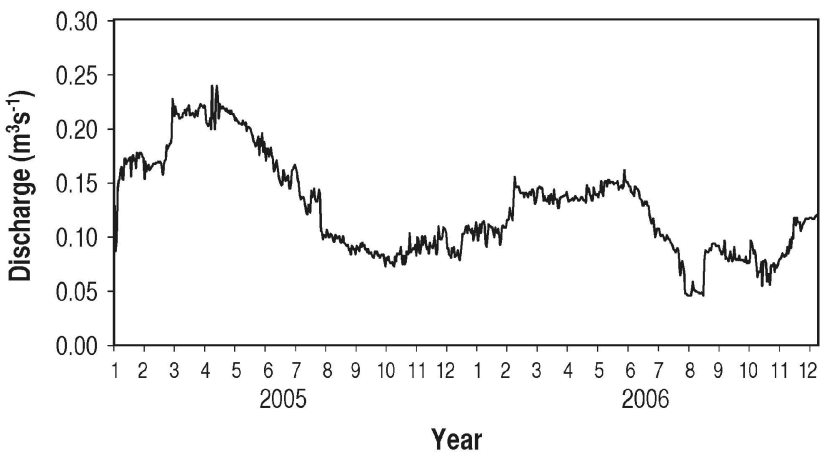

Figure 4. Hydrograph of mean daily discharge for the Little Stour River at Littlebourne (2005-2006)

(Tukey's post-hoc test: all $P<0.05)$ than all other months (Figure 5c)

The abundance of invertebrates within the hyporheic zone was significantly different between months $\left(F_{6,140}=21 \cdot 02, \quad P<0 \cdot 001\right)$. Hyporheic abundances increased significantly in July and September (Tukey's post-hoc test: all $P<0.005)$ but were reduced during August and October (Figure 6a). The number of taxa recorded in hyporheic samples also differed significantly between months $\left(F_{6,140}=14.43, P<0.001\right)$. This was
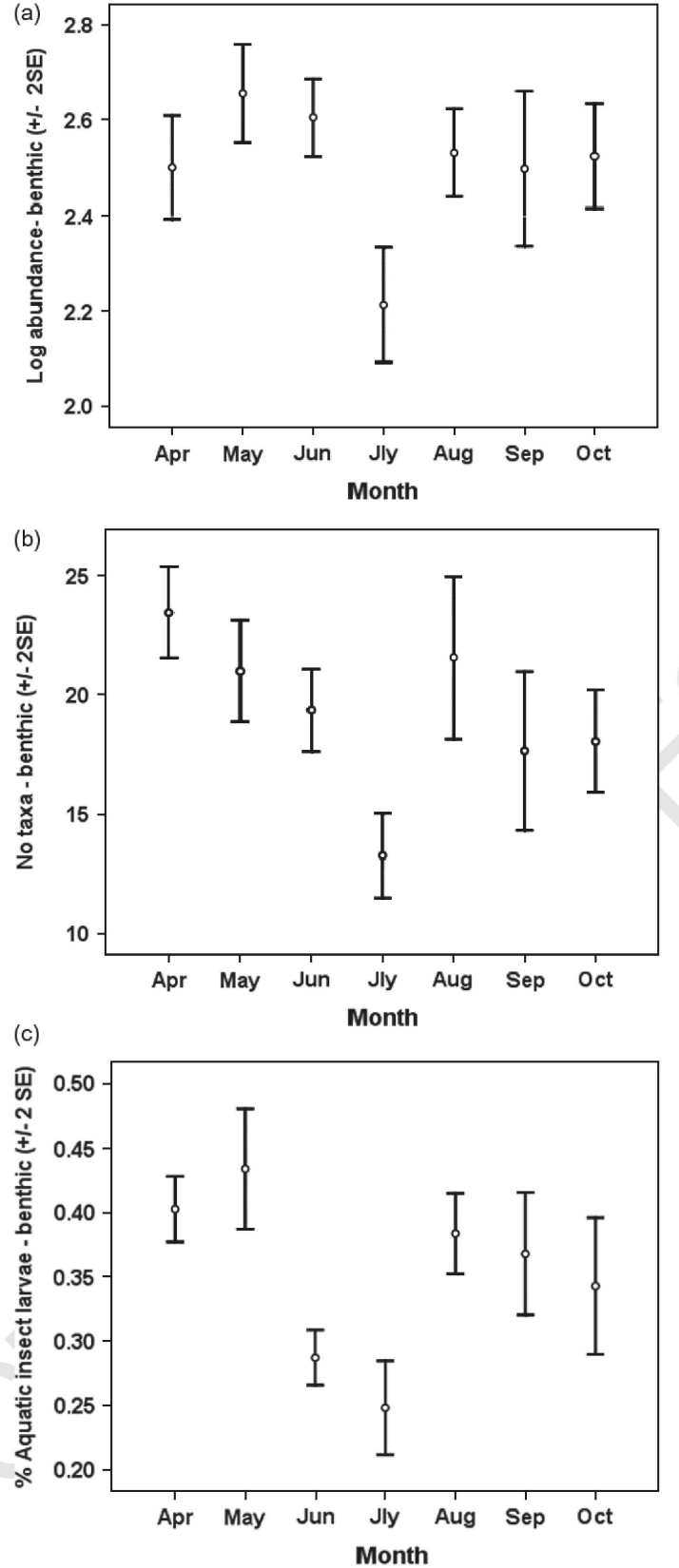

Figure 5. Little Stour benthic assemblage response (April-October 2006) during the final stages of a supra-seasonal drought event (2004-2006). Mean ( $+/-2$ standard error) of: (a) abundance of macroinvertebrates, (b) number of taxa and (c) percentage of aquatic insect larvae within samples

almost exclusively due to a significant increase in the number of taxa recorded in September (Tukey's posthoc test: all $P<0.001$ ) (Figure $6 \mathrm{~b}$ ) coinciding with an

Table II. Summary of mean monthly maximum and minimum daily temperature (with standard deviation in brackets) at Manston (Kent), and mean monthly benthic and hyporheic water temperature recorded at the study sites (April-October 2006)

\begin{tabular}{|c|c|c|c|c|c|c|c|}
\hline & April & May & June & July & August & September & October \\
\hline Max air temperature $\left({ }^{\circ} \mathrm{C}\right)$ & $14 \cdot 2(2 \cdot 2)$ & $13 \cdot 5(2 \cdot 4)$ & $17 \cdot 2(2 \cdot 9)$ & $21 \cdot 9(2 \cdot 1)$ & $17.7(1.7)$ & $18 \cdot 8(1 \cdot 7)$ & $15 \cdot 1(1.4)$ \\
\hline Min air temperature $\left({ }^{\circ} \mathrm{C}\right)$ & $8 \cdot 6(2 \cdot 3)$ & $9.3(1.9)$ & $11 \cdot 3(2 \cdot 7)$ & $15 \cdot 6(1.7)$ & $13.4(1.4)$ & $14.7(1.7)$ & $11.8(2.5)$ \\
\hline Water temperature $\left({ }^{\circ} \mathrm{C}\right)$ & $9 \cdot 4(0 \cdot 5)$ & $12 \cdot 8(1 \cdot 8)$ & $16 \cdot 5(2 \cdot 5)$ & $18 \cdot 6(3 \cdot 1)$ & $14 \cdot 2(1 \cdot 2)$ & $14 \cdot 6(1 \cdot 1)$ & $12.4(0.8)$ \\
\hline Hyporheic temperature $\left({ }^{\circ} \mathrm{C}\right)$ & $8 \cdot 1(0 \cdot 5)$ & $10 \cdot 9(1.7)$ & $14 \cdot 1(2 \cdot 2)$ & $16 \cdot 6(2 \cdot 1)$ & $12 \cdot 3(1 \cdot 1)$ & $13 \cdot 1(1 \cdot 0)$ & $10.4(0.7)$ \\
\hline
\end{tabular}

Benthic and hyporheic water samples were recorded at five locations from four sites $(n=20)$ each month.

Hydrol. Process. 23, 0-0 (2009) DOI: $10.1002 /$ hyp 

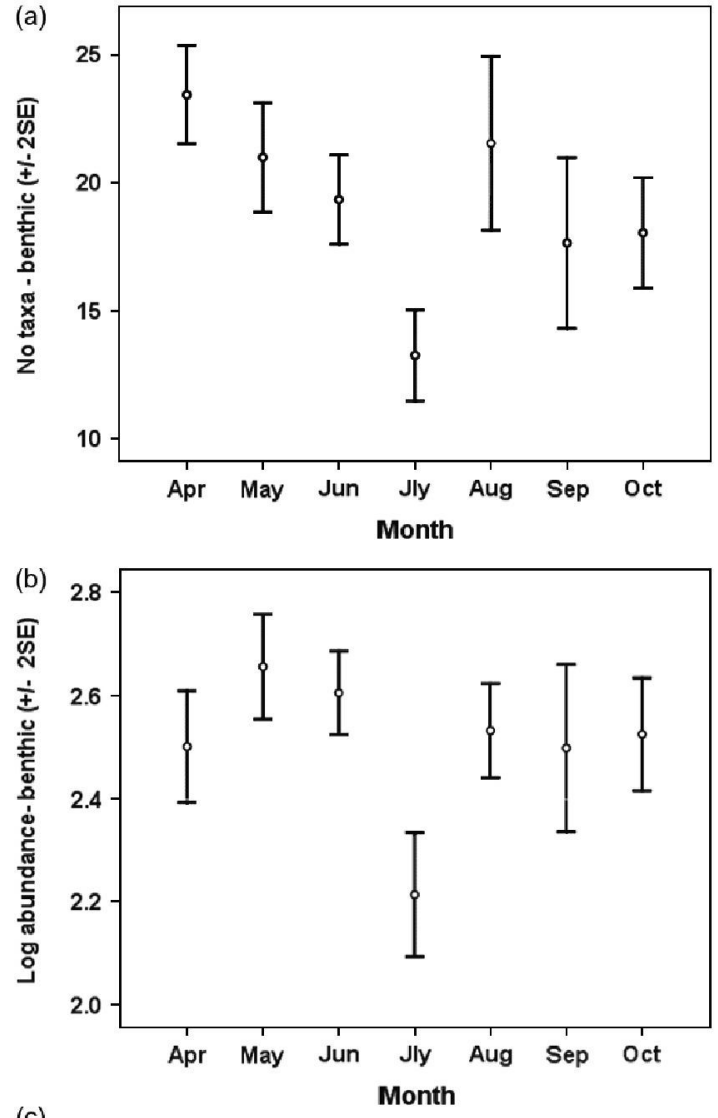

(c)

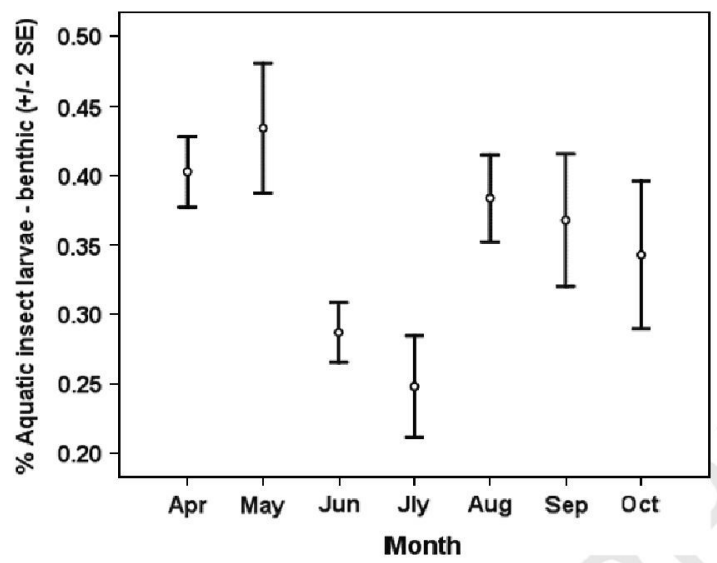

Figure 6. Little Stour hyporheic assemblage response (April-October 2006) during the final stages of a supra-seasonal drought event (2004-2006). Mean (+/-2 standard error) of: (a) abundance of macroinvertebrates and (b) number of taxa

1 increase in obligate hyporheic taxa including Proasellus

2 cavaticus, Niphargus aquilex and N. fontanus.

Effects of drought on benthic and hyporheic invertebrate

The long-term data from the Little Stour clearly demonstrates that, on an inter-annual basis, the number of taxa and the number of individuals per sample appear to respond to the volume of discharge. Periods of supra-seasonal drought significantly reduced taxa richness and numbers of individuals over multiple events of varying duration. This corroborates the pattern predicted for benthic fauna hypothesized by Boulton (2003), and summarized in Figure 1, although the inter-annual response of hyporheic fauna to river flow variability remains unknown. The changes in benthic taxa richness and the number of individuals per sample may reflect differences in habitat availability within the channel during drought conditions and the loss or contraction of important habitats such as clean gravels and river margin habitats under low-flow conditions (Harrison, 2000), and also modified life history schedules (particularly emergence of adult) of aquatic insects during extended droughts (Lake, 2003).

Periods of drought-related low flows have the potential to significantly modify in-stream communities in both naturally intermittent and perennial lotic systems (Boulton, 2003; Wood and Armitage, 2004; Lake, 2007). Short duration meteorological or hydrological droughts may significantly modify benthic communities in naturally intermittent systems (Boulton and Lake, 1992; Acuna et al., 2005) but may have limited or even undetectable impacts within perennial streams due to the buffering effect of baseflow from groundwater sources (Wood, 1998; Humphries and Baldwin, 2003; Lake, 2003). Supra-seasonal groundwater droughts also lead to significant changes in water quality (Parr and Mason, 2003; Suren et al., 2003), reduction of in-stream habitat availability and diversity, and changes to benthic community structure and composition (Extence, 1981; Lake, 2003; Dewson et al., 2007), particularly if the community is not adapted to extreme low flows or drying (Lytle and Poff, 2004). However, it may take some time for the impact of drought on in-stream ecology to become apparent in groundwater-dominated systems (Wright and Symes, 1999; Wood and Armitage, 2004). Antecedent hydrological conditions are critical to determining the recession of flow during droughts (Marsh et al., 2007) and this, in turn, is a primary factor influencing the ability of in-stream communities to withstand the hydrological disturbance (Humphries and Baldwin, 2003; Lake, 2007).

Knowledge regarding the response of hyporheic communities to low flows and drought is limited and is largely confined to naturally intermittent systems where hyporheic communities have been monitored following the cessation of surface flows (Boulton and Stanley, 1995; Clinton et al., 1996; del Rosario and Resh, 2000; Hose et al., 2005). Only a single study has simultaneously considered the response of both benthic and hyporheic invertebrate communities to experimental low flows and this indicated no deleterious impacts on pool-dwelling 110 invertebrates or on the abundance or vertical distribution 111 of hyporheic macroinvertebrates as long as flow persisted 112 (James et al., 2008).

The intensive short-term study associated with the final 114 stages of the supra-seasonal drought in 2006 suggested 115 that the response of the benthic fauna is governed by 116 a range of factors in addition to flow (discharge) as the 117 lowest species richness and abundance did not correspond 118 
with the period of lowest flows. These changes coincide with the emergence of many aquatic insect taxa from the benthos and means isolating the effect of drought from natural life history characteristics is not possible unless considered alongside long-term data (Lake, 2003), which indicates that emergence of many insects occurred earlier in 2006 drought than in non-drought years. The hyporheic community responded differently to the benthos to the changes in flow and water level during the study period. Therefore, it cannot be assumed that the impact of low flow/drought upon benthic communities and the response of fauna inhabiting the hyporheic zone will be the same. This should not be unexpected because the reduction in the volume of water and the ultimate dewatering of the channel will occur within benthic habitats before water level changes within hyporheic habitats. The results of this study suggest that other abiotic parameters, such as thermal characteristics, may be significant factors structuring both communities during supra-seasonal drought.

A conceptual model of low flow and drought influences on ecologically significant processes and interactions between the benthic and hyporheic zones

The potential influences of changes in river flow and associated abiotic factors on benthic and hyporheic communities can be hypothesized, drawing on sources from the hydrological, sedimentological and ecological literature. The conceptual model outlined in Figure 8 specifically considers the processes and interactions that may influence invertebrate communities within the hyporheic zone during periods of low flow and stream bed drying associated with surface water and groundwater drought. To our knowledge, this is the first attempt that has been made to integrate abiotic drivers with likely responses by benthic and hyporheic stream invertebrates, and provides

(a)

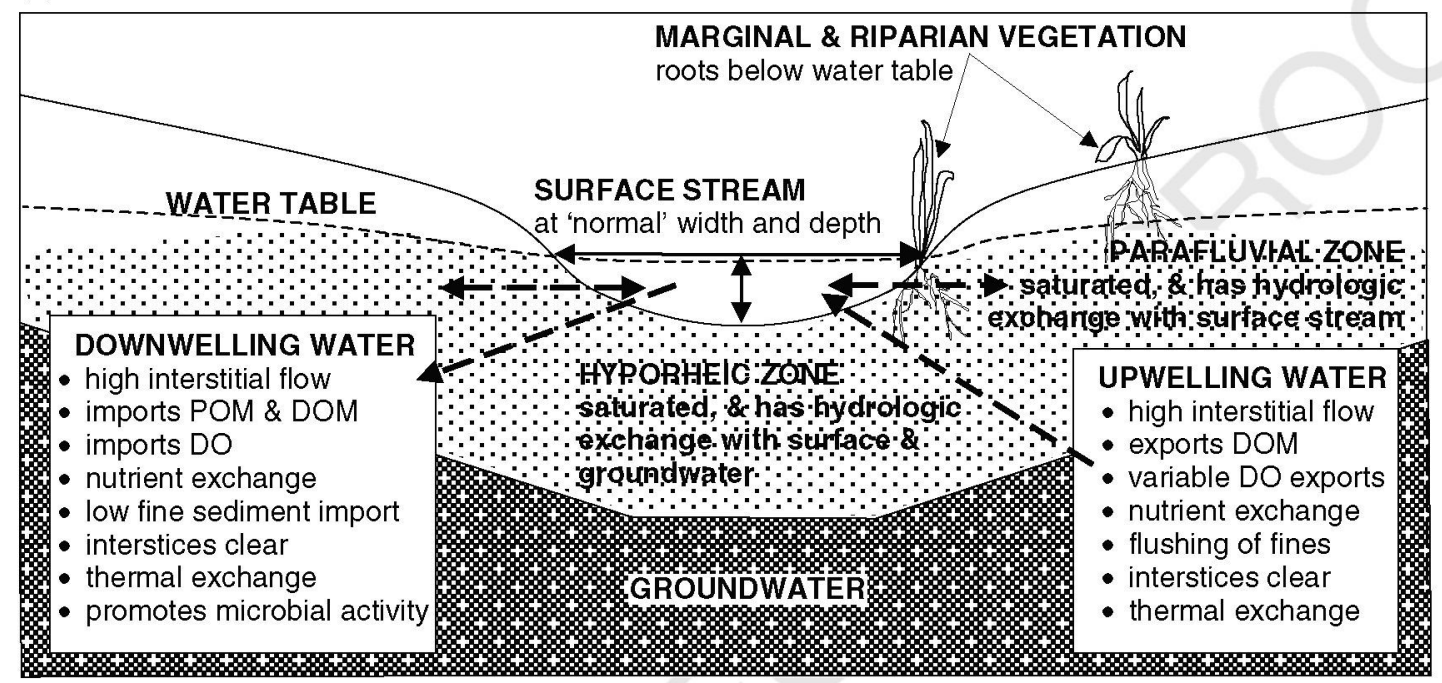

(b)

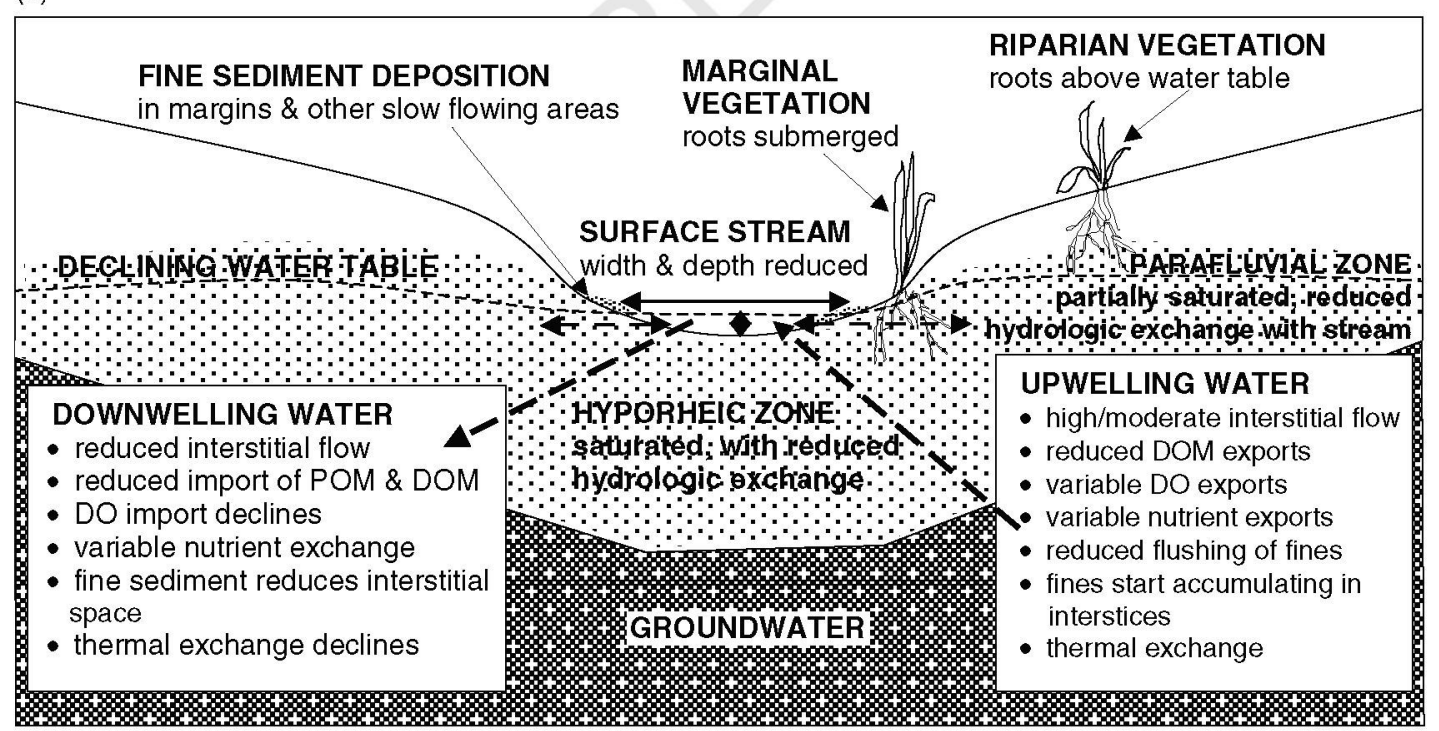

Figure 7. Conceptual model of ecologically significant processes and interactions between the benthic and hyporheic zones as a result of low flow and supra-seasonal drought: (a) unimpaired flow; (b) low/base flow; (c) loss of surface water and (d) decline of water level within the hyporheic zone 
(c)

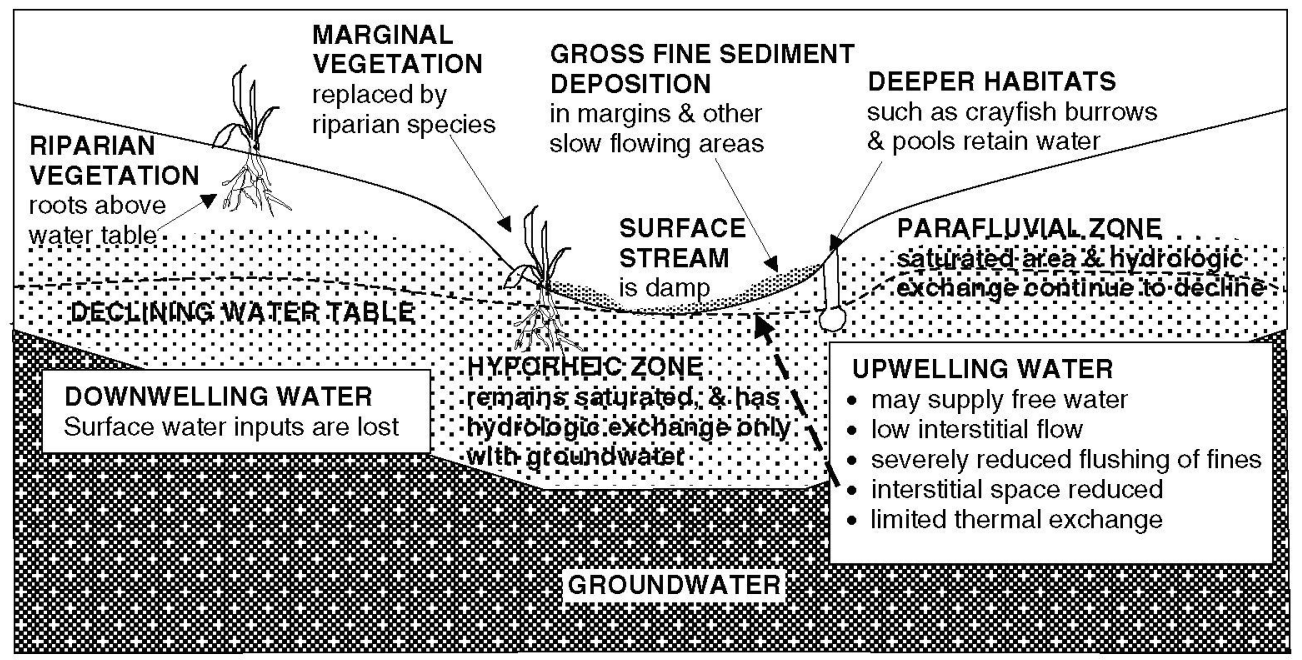

(d)

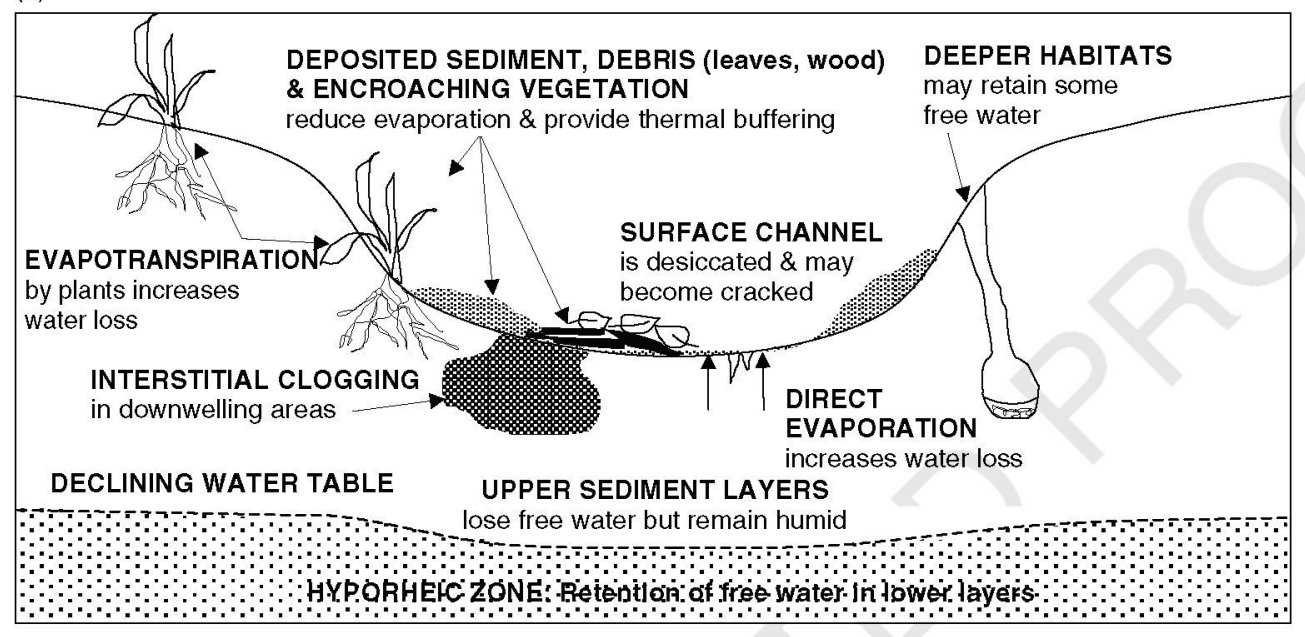

Figure 7. (Continued)

an insight into the potential impacts of anthropogenic activities on these subsystems and the hydrological linkages between them, especially during drought.

When river flow and bed integrity are unimpaired, the hyporheic zone and the adjacent parafluvial zone (sensu Boulton et al., 1998) will be saturated, allowing both vertical and lateral hydrological exchange (Stanford and Ward, 1993; Malard et al., 2002). The nature of physical and biogeochemical interactions occurring within the hyporheic zone will be strongly influenced by the direction of hydrological exchange (upwelling groundwater or downwelling surface water) and the flow velocity (Figure 7a). Local differences in the nature of these exchanges will be influenced by floodplain and channel morphology (Stanford and Ward, 1993) and at smaller scales by individual riffle, pool and bar sequences (Lefebvre et al., 2006) and even individual bed elements (Boulton, 2007) which may result in micro-scale patch variability in faunal distributions (Dole-Olivier and Marmonier, 1992; Davy-Bowker et al., 2006). Unimpaired hydrological exchanges within the hyporheic zone promotes thermal exchange (Hannah et al., 2008), the maintenance of hyporheic interstitial permeability, porosity and flow velocities (Malcolm et al., 2005) and in-stream storage or export of nutrients (Figure 7a). As a result, the hyporheic zone may be one of the primary locations for the processing of nutrients and dissolved and particulate organic matter within some systems (Mulholland et al., 2008; Pinay et al., 2009) particularly through microbial activity (Hendricks, 1993; Marxsen, 2006).

As flow declines as a drought proceeds, exchange processes and connectivity between the hyporheic zone and the adjacent parafluvial will be reduced (Figure $7 b$ ). Riparian vegetation may begin to experience water stress, and marginal and in-stream vegetation will become partially or even fully exposed. Depending on whether water is locally upwelling or downwelling, the hyporheic zone may still function as a transient store or source of solutes (Stofleth et al., 2008), although the rate of exchange is likely to be significantly reduced. In the absence of flushing flows, fine sediments ( $<2 \mathrm{~mm}$ in size $)$ may be deposited onto the bed, infiltrating and potentially clogging the interstices within the benthic and hyporheic zones (Brunke, 1999). This reduces the competency of exchange processes and the porosity and permeability of the sediments (Bo et al., 2007; Meyer et al., 2008), 
with consequences for the supply of dissolved solutes and hyporheic oxygen (Youngson et al., 2004). It also reduces living space for larger hyporheic invertebrates as well as sediment-associated benthos. The fine sediments may also be stabilized by the development of autochthonous biofilms and algal mats, further exacerbating the situation (Battin, 2000).

In many naturally intermittent rivers (in semi-arid and temperate regions) or during high magnitude supraseasonal droughts within environments where surface flow is usually perennial, flow may almost cease and water becomes isolated within pools, although the hyporheic zone usually remains saturated (Figure 7c). As surface and groundwater levels decline, lateral interactions with the parafluvial zone may diminish or cease. Riparian and marginal vegetation typically experience significant water stress and aquatic macrophytes may be eliminated (Westwood et al., 2006). Fine sediments often form a relatively impermeable crust over the substratum of the bed, beneath which anoxic conditions may exist (Smock et al., 1994). Water within the hyporheic zone will continue to travel downstream and local upwelling may supply free water, maintaining a limited interstitial habitat and thermal regime within the tolerance limits of some fauna (Hose et al., 2005). However, the chemical characteristics of this hyporheic water are likely to be altered by the reduced interaction with surface waters as well as the deteriorating water quality typical of drying streams.

If drought conditions persist, levels of water within the hyporheic zone may decline, ultimately leading to the desiccation of benthic then hyporheic sediments (Figure 7d). The habitat available for aquatic organisms will become extremely limited, although refugia may exist in the form of moisture-retaining pockets of organic matter on the bed or at the margins, deeper burrows excavated by organisms such as crayfish, and hyporheic sediments that retain a high humidity (Boulton, 1989; Fenoglio et al., 2006). Some aquatic taxa, particularly in systems with predictable periods of stream bed drying, display life-cycle adaptations such as diapause to withstand the desiccation (Boulton, 2003; Williams, 2006). Under extreme supra-seasonal groundwater drought conditions, exchange processes within the hyporheic zone may all cease until groundwater levels begin to recover.

\section{A landscape perspective}

Drought is a large-scale phenomenon (Lake, 2003) and when the conceptual model outlined earlier is placed in

(a)

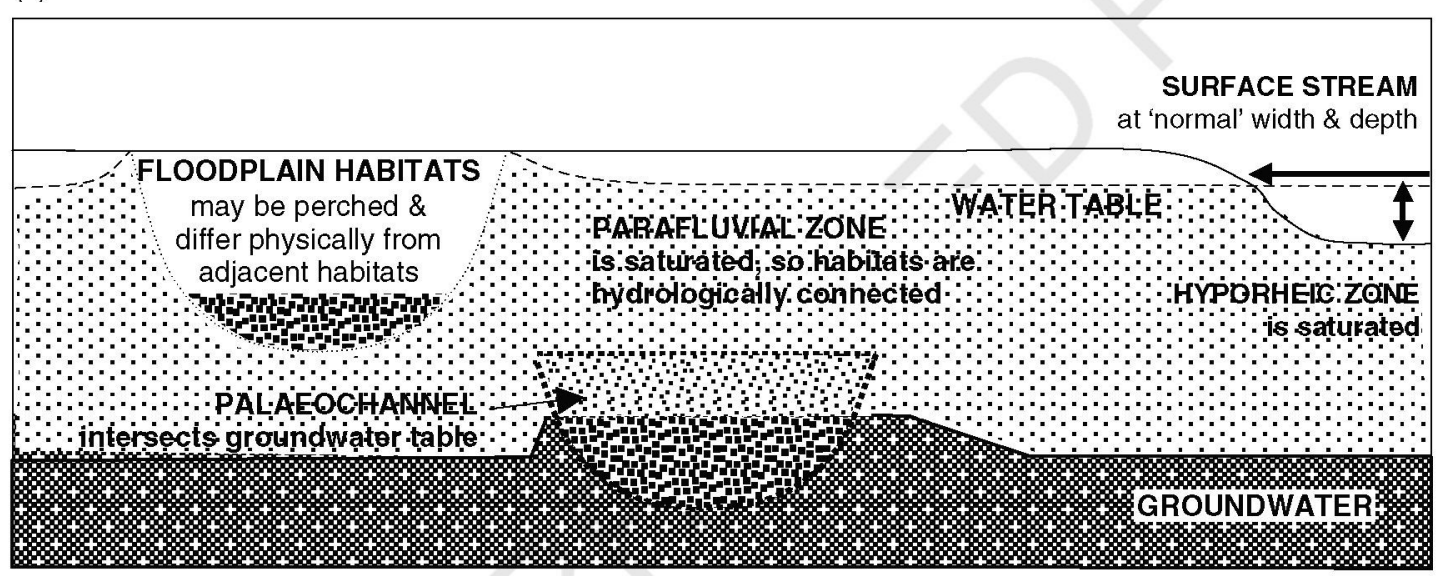

(b)

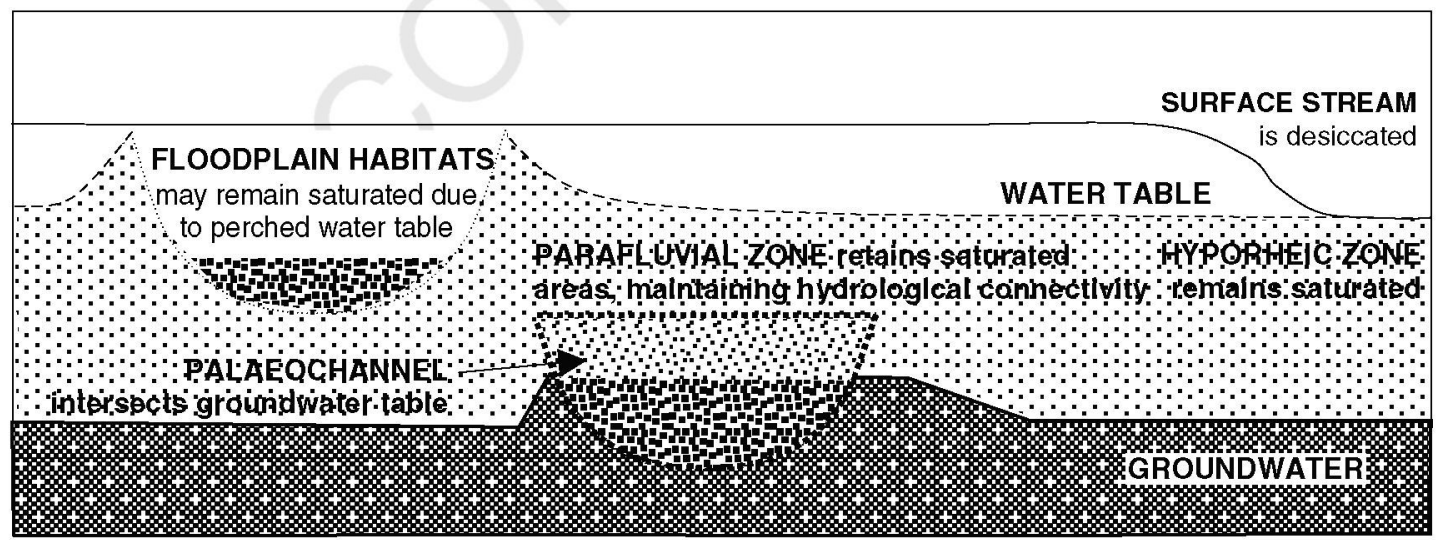

Figure 8. Conceptual model of the 'hyporheic corridor' from a landscape perspective indicating floodplain habitats such as ponds, pools, oxbow lakes and palaeochannels: (a) lateral connectivity of the hyporheic corridor during unimpaired flow and (b) lateral connectivity when surface flow in the river channel has ceased 
a landscape perspective, the potential scale and significance of processes operating along the "hyporheic corridor' (sensu Stanford and Ward, 1993) or within the 'stygoscape' (sensu Datry et al., 2008) becomes apparent. The lateral connectivity of alluvial sediments and differential permeability associated with paleochannels and floodplain water bodies, such as ponds, cutoffs and backwater channels, provide corridors along which water and biota may be able to move (Figure 8 ). These differences in sedimentary characteristics may lead locally to elevated (perched) water tables (Malard et al., 2002), which may provide small areas of surface water that persist even when flow in adjacent rivers has ceased (Figure 8b). This landscape perspective also demonstrates the refugial potential of the 'hyporheic corridor' for both hypogean and surface water fauna, respectively (Harris et al., 2002). When this landscape perspective is extended to consider the wider drainage basin, the 'stygoscape' clearly extends into headwater streams and springs (Wood et al., 2005) and truly subterranean habitats including cave ecosystems (Gibert and Deharveng, 2002). The potential influence of supra-seasonal groundwater drought upon subterranean ecosystems has not been widely considered to date due to the widely perceived stability of these environments and communities they support. However, the pervasive vertical hydrological linkages across the drainage basin, via hyporheic zones and shallow aquifers clearly have potential to structure communities in these habitats and affect refugial areas for surface communities. These environments and their fauna may not be so stable after all, especially during hydrological and groundwater droughts.

\section{CONCLUSION}

In-stream faunal responses to low flows and drought are frequently overlooked or only considered once the event has proceeded for many months or seasons. By which time, significant changes have often already occurred. To compound these problems, the extended and 'creeping' nature of groundwater droughts do not easily fit the timeframe of most research projects (Lake, 2003). The results of this research demonstrate the temporal impact of groundwater drought on surface and subsurface faunal assemblages at scales of individual in-stream habitats (riffles) to the landscape perspective hypothesized in our conceptual models. The research also illustrates the importance of considering lagged effects in response to hydrological inputs (precipitation) both during and following periods of drought. This is particularly important in areas subject to extended supra-seasonal groundwater droughts as the response of the aquatic faunal community is a function of the conditions within the underlying aquifer, hyporheic and parafluvial zones. In most streams, recovery of flow and the aquatic invertebrate community will only occur once the aquifer, parafluvial and hyporheic zones are fully saturated.
Until stream hydrologists, ecologists and river managers fully appreciate the interactions between groundwater, the hyporheic zone and the surface stream, our understanding of the effects of drought on microbial processes and the invertebrates inhabiting the hyporheic and benthic zones will be severely constrained. We contend that disappearance or reappearance of surface water is only part of the dynamic in-streams subject to drought and we urge further integrated research on surface and subsurface habitats to test hypotheses derived from our conceptual model. Currently, the model is a static one and as we learn more about the effects of antecedent conditions, we will be able to add the crucial temporal component that could predict the effects of 'drought history' on surface and hyporheic assemblages, with obvious implications for understanding the effects of climate change and anthropogenic modifications of flow regime.

\section{ACKNOWLEDGEMENTS}

The authors gratefully acknowledge the continued cooperation of the Environment Agency of England and Wales and particularly Ian Humpheryes, Shelagh Wilson and Kevin Grimmett. Part of this research was supported by a Natural Environment Research Council Urgency Grant (NE/E001769/1) entitled 'The response of aquatic invertebrate fauna to supra-seasonal drought and drying in a largely perennial chalk stream'. Meteorological data for Manston (Kent) were kindly supplied by the British Atmospheric Data Centre (BADC). Thanks to Sally Little for technical and laboratory support and Mark Szegner (Department of Geography, Loughborough University) for assistance with the production of figures. We would like to thank two anonymous reviewers for their helpful and constructive comments on a draft of this manuscript which helped improve the clarity of the paper in a number of areas.

$\begin{array}{rr} & 97 \\ & 98 \\ \text { REFERENCES } & 99 \\ & 100\end{array}$

Acuna V, Munoz I, Giorgi A, Omella M, Sabater F, Sabater S. 2005. Drought and post drought recovery cycles in an intermittent Mediterranean stream: structural and functional aspects. Journal of the North American Benthological Society 24: 919-933.

Battin TJ. 2000. Hydrodynamics is a major determinant of streambed biofilm activity: From the sediment to the reach scale. Limnology and Oceanography 45: 1308-1319.

Bo T, Fenoglio S, Malacarne G, Pessino M, Sgariboldi F. 2007. Effect of clogging on stream macroinvertebrates: An experimental approach. Limnologica 37: 186-192.

Bonada N, Rieradevall M, Prat N, Resh VH. 2006. Benthic macroinvertebrate assemblages and microhabitat connectivity in Mediterraneanclimate streams of southern California. Joumal of the North American Benthological Society 25: 32-43.

Bou C, Rouch R. 1967. Un nouveau champ de recherches sur la faune aquatique souterainne. Comptes Rendus Academie des Sciences Paris 265: $369-370$

Boulton AJ. 1989. Over-summer refuges of aquatic macroinvertebrates in 114 two intermittent streams in central Victoria. Transactions of the Royal 115 Society of South Australia 113: 22-34.

Boulton AJ. 2003. Parallels and contrasts in the effects of drought 116 on stream macroinvertebrate assemblages. Freshwater Biology 48: 117 $1173-1185$. 
Boulton AJ. 2007. Hyporheic rehabilitation in rivers: restoring vertical connectivity. Freshwater Biology 52: 632-650.

Boulton AJ, Fenwick G, Hancock PJ, Harvey MS. 2008. Biodiversity, functional roles and ecosystem services of groundwater invertebrates. Invertebrate Systematics 22: $103-116$.

Boulton AJ, Findlay S, Marmonier P, Stanley EH, Valett HM. 1998. The functional significance of the hyporheic zone in streams and rivers. Annual Review of Ecology and Systematics 29: 59-81.

Boulton AJ, Lake PS. 1992. The ecology of two intermittent streams in Victoria, Australia. II. Comparisons of faunal composition between habitats, rivers and years. Freshwater Biology 27: 99-121.

Boulton AJ, Stanley EH. 1995. Hyporheic processes during flooding and drying in a Sonoran Desert stream. 2. Faunal dynamics. Archiv Fur Hydrobiologie 134: 27-52.

Brunke M. 1999. Colmation and depth filtration within streambeds: Retention of particles in the hyporheic interstices. Intemational Review of Hydrobiology 84: 99-117.

Caruso BS. 2002. Temporal and spatial patterns of extreme low flows and effects on stream ecosystems in Otago, New Zealand. Joumal of Hydrology 257: 115-133.

Clinton SM, Grimm NB, Fisher SG. 1996. Response of a hyporheic invertebrate assemblage to drying disturbance in a desert stream. Joumal of the North American Benthological Society 15: 700-712.

Datry T, Scarsbrook MS, Larned S, Fenwick G. 2008. Lateral and longitudinal patterns within the stygoscape of an alluvial river corridor. Fundamental and Applied Limnology 171: 335-347.

Davy-Bowker J, Sweeting W, Wright N, Clarke RT, Armott S. 2006. The distribution of benthic and hyporheic macroinvertebrates from the heads and tails of riffles. Hydrobiologia 563: 109-123.

del Rosario RB, Resh VH. 2000. Invertebrates in intermittent and temporary streams: Is the hyporheic zone a refuge from drying? Joumal of the North American Benthological Society 19:680-696.

Demuth S, Young AR. 2004. Regionalization procedures. Hydrological Drought: Process and Estimation Methods for Streamflow and Groundwater, Developments in Water Science 48, Tallakse LM, Van Lanen HAJ (eds). Elsevier: Amsterdam; 307-343.

Dewson ZL, James ABW, Death RG. 2007. A review of the consequences of decreased flow for instream habitat and macroinvertebrates. Joumal of the North American Benthological Society 26: 401-415.

Dole-Olivier MJ, Marmonier P. 1992. Patch distribution of interstitial communities: prevailing factors. Freshwater Biology 27: 177-191.

Extence CA. 1981. The effect of drought on benthic invertebrate communities in a lowland river. Hydrobiologia 83: 217-224.

Fenoglio S, Bo T, Bosi G. 2006. Deep interstitial habitat as a refuge for Agabus paludosus (Fabricus) (Coleoptera: Dytiscidae) during summer droughts. Coleopterists Bulletin 60; 37-41.

Gibert J, Deharveng L. 2002. Subterranean ecosystems: A truncated functional biodiversity. Bioscience 52: 473-481.

Hannah DM, Malcolm IA, Soulsby C, Youngson AF. 2008. A comparison of forest and moorland stream microclimate, heat exchange and thermal dynamics. Hydrological Processes 22: 919-940.

Harris PM, Roosa BR, Norment L. 2002. Underground dispersal by amphipods (Crangonyx pseudogracilis) between temporary ponds. Journal of Freshwater Ecology 17: 589-594.

Harrison SSC. 2000. The importance of aquatic margins to invertebrates in English chalk streams. Archiv fur Hydrobiologie 149: 213-240.

Hendricks SP. 1993. Microbial ecology of the hyporheic zone: a perspective integrating hydrology and biology. Journal of the North American Benthological Society 12: 70-78.

Hose GC, Jones P, Lim RP. 2005. Hyporheic macroinvertebrates in riffle and pool areas of temporary streams in south eastern Australia. Hydrobiologia 532: $81-90$.

Humphries P, Baldwin DS. 2003. Drought and aquatic ecosystems: an introduction. Freshwater Biology 48: 1141-1146.

James BW, Dewson ZS, Death RG. 2008. Do stream invertebrates use instream refugia in response to severe short-term flow reduction in New Zealand streams? Freshwater Biology 53: 1316-1334.

Lake PS. 2003. Ecological effects of perturbations by drought in flowing waters. Freshwater Biology 48: 1161-1172.

Lake PS. 2007. Flow generated disturbances and ecological responses: floods and droughts. In Hydroecology and Ecohydrology: Past, Present and Future, Wood PJ, Hannah DM, Sadler JP (eds). Wiley: Chichester; 75-92.

Lefebvre S, Marmonier P, Peiry JL. 2006. Nitrogen dynamics in rural streams: differences between geomorphic units. Annales de Limnologie - Intemational Joumal of Limnology 42: 43-52.

Lytle DA, Poff NL. 2004. Adaptation to natural flow regimes. Trends in Ecology \& Evolution 19: 94-100.
Malard F, Tockner K, Dole-Oliver MJ, Ward JV. 2002. A landscape perspective of surface-subsurface hydrological exchanges in river corridors. Freshwater Biology 47: 621-640.

Malcolm IA, Soulsby C, Youngson AF, Hannah DM. 2005. Catchmentscale controls on groundwater-surface water interactions in the hyporheic zone: Implications for Salmon embryo survival. River Research and Applications 21: 977-989.

Marsh T. 2007. The 2004-2006 drought in southern Britain. Weather 62 191-196.

Marsh T, Cole G, Wilby R. 2007. Major droughts in England and Wales, 1800-2006. Weather 62: 87-93.

Marxsen J. 2006. Bacterial production in the carbon flow of a central European stream, the Breitenbach. Freshwater Biology 51: 1838-1861.

Meyer EI, Niepagenkemper O, Molls F, Spanhoff B. 2008. An experimental assessment of the effectiveness of gravel cleaning operations in improving hyporheic water quality in potential salmonid spawning areas. River Research and Applications 24: 119-131.

Monk WA, Wood PJ, Hannah DM, Wilson DA. 2008. Macroinvertebrate community response to inter-annual and regional river flow regime dynamics. River Research and Applications 24: 988-1001.

Mulholland PJ, Helton AM, Poole GC, Hall RO, Hamilton SK, • et al 2008. Stream denitification across biomes and its response to anthropogenic nitrate loading. Nature 452: 202-205.

Parr LB, Mason CF. 2003. Long-term trends in water quality and their impact on macroinvertebrate assemblages in eutrophic lowland rivers. Water Research 37: 2969-2979.

Pinay G, O'Keefe TC, Edwards RT, Niaman RJ. 2009. Nitrate removal in the hyporheic zone of a salmon river in Alaska. •River Research and Applications DOI: $10 \cdot 1002 / \mathrm{rra} .1164$.

Prior J, Beswick M. 2007. The record-breaking heat and sunshine of July 2006. Weather 62: 174-182.

Smakhtin VU. 2001. Low flow hydrology: a review. Joumal of Hydrology 240: $147-186$

Smakhtin VU, Schipper ELF. 2008. Droughts: The impact of semantics and perceptions. Water Policy 10: 131-143.

Smock LA, Smith LC, Jones JB Jr, Hooper SM. 1994. Effects of drought and hurricane on a coastal headwater stream. Archiv für Hydrobiologie 131: $25-38$.

Stanford JA, Ward JV. 1993. An ecosystem perspective of alluvial rivers: connectivity and the hyporheic corridor. Joumal of the North American Benthological Society 12: 48-60.

Stofleth JM, Shields FD, Fox GA. 2008. Hyporheic and total transient storage in small, sand-bed streams. Hydrological Processes 22 $1885-1894$.

Suren AM, Biggs BJF, Duncan MJ, Bergy L, Lambert P. 2003. Benthic community dynamics during summer low-flows in two rivers of contrasting enrichment 2. Invertebrates. New Zeland Journal of Marine and Freshwater Research 37: 71-83.

Suren AM, Jowett IG. 2006. Effects of floods versus low flows on invertebrates in a New Zealand gravel-bed river. Freshwater Biology 51: $2207-2227$.

Tallaksen LM, van Lanen HAJ. 2004. Introduction. In Hydrological Drought: Process and Estimation Methods for Streamflow and Groundwater, Developments in Water Science 48, Tallakse LM, Van Lanen HAJ (eds). Elsevier: Amsterdam; 3-17.

Tomlinson M, Boulton AJ, Hancock PJ, Cook PG. 2007. Deliberate omission or unfortunate oversight: Should stygofaunal surveys be included in routine groundwater monitoring programs? Hydrogeology Journal 15: $1317-1320$.

Westwood CG, Teeuw RM, Wade PM, Holmes NTH, Guyard P. 2006. Influences of environmental conditions on macrophyte communities in drought-affected headwater streams. River Research and Applications 22. $703-726$.

Williams DD. 2006. The Biology of Temporary Waters. Oxford University Press: Oxford; 337.

Wood PJ. 1998. The ecological impact of the 1995-1996 drought on a small groundwater-fed stream. In Hydrology in a Changing Environment, Vol. 1, Wheaten H, Kirby C (eds). Wiley: Chichester; $301-311$.

Wood PJ, Agnew MD, Petts GE. 2000. Flow variations and macroinvertebrate community responses in a small groundwater-dominated stream in south-east England. Hydrological Processes 14: 3133-3147.

Wood PJ, Armitage PD. 2004. The response of the macroinvertebrate community to low-flow variability and supra-seasonal drought within a groundwater dominated stream. Archiv fïr Hydrobiologie 161: 1-20.

Wood PJ, Gunn J, Smith H, Abas-Kutty A. 2005. Flow permanence and macroinvertebrate community diversity within groundwater dominated headwater streams and springs. Hydrobiologia 545: 55-64. 
Wood PJ, Petts GE. 1994. Low flows and recovery of macroinvertebrates in a small regulated chalk stream. Regulated Rivers-Research \& Management 9: 303-316.

Wood PJ, Petts GE. 1999. The influence of drought on chalk stream macroinvertebrates. Hydrological Processes 13: 387-399.

Wright JF, Berrie AD. 1987. Ecological effects of groundwater pumping and a natural drought on the upper reaches of a chalk stream. Regulated Rivers-Research \& Management 1: 145-160.
Wright JF, Symes KL. 1999. A nine-year study of the macroinvertebrate fauna of a chalk stream. Hydrological Processes 13: 371-385.

Youngson AF, Malcolm IA. Thorley JL, Bacon PJ, Soulsby C. 2004.

Long-residence groundwater effects on incubating salmonid redds: low hyporheic oxygen impairs embryo development. Canadian Joumal of Fisheries and Aquatic Sciences 61: 2278-2287. 